\title{
Response of Soybean (Glycine max L.) to Rhizobia Inoculation and Molybdenum Application in the Northern Savannah Zones of Ghana
}

\author{
Asei Rechiatu' ${ }^{1}$, Ewusi-Mensah Nana ${ }^{1}$, Abaidoo Robert Clement ${ }^{2}$ \\ ${ }^{1}$ Dept. of Crop and Soil Sciences, Kwame Nkrumah University of Science and Technology, Kumasi, Ghana \\ ${ }^{2}$ Dept. of Theoretical and Applied Biology, Kwame Nkrumah University of Science and Technology, Kumasi, Ghana \\ Email address: \\ remaraib@yahoo.com (Asei R.), nanaewusi@yahoo.com (Ewusi-Mensah N.), abaidoorc@yahoo.com (Abaidoo R. C.)
}

\section{To cite this article:}

Asei Rechiatu, Ewusi-Mensah Nana, Abaidoo Robert Clement. Response of Soybean (Glycine max L.) to Rhizobia Inoculation and Molybdenum Application in the Northern Savannah Zones of Ghana. Journal of Plant Sciences. Vol. 3, No. 2, 2015, pp. 64-70.

doi: $10.11648 /$ j.jps.20150302.14

\begin{abstract}
Compatible rhizobia populations are seldom available in soils where soybean has not been grown before. Inoculating soybean seeds with superior rhizobia strains is necessary for nodulation and nitrogen fixation. Ironically, many commercial agricultural products (biological and chemical) claim increases in crop productivity but their efficacy cannot be guaranteed. Thus, three separate on-station trials (Manga, Kpongu and Nyankpala) were conducted at the experimental fields of CSIR-Savannah Agricultural Research Institute (SARI), to ascertain the effectiveness of some commercial microbial inoculant and micronutrient fertilizer for improvement of soybean productivity in the Northern savannah zones of Ghana. Four treatments were used for each study site; Control, Teprosyn Mo, Legumefix and Teprosyn Mo+Legumefix which were laid out in a Randomised Complete Block Design (RCBD) with three replications. Experimental plots measured $4.5 \mathrm{~m} \times 4.5 \mathrm{~m}$. A significant $(\mathrm{P}<0.05)$ response of soybean nodule dry weight to Legumefix was observed in Kpongu and Manga but not Nyankpala. At harvest, Teprosyn Mo+Legumefix, Legumefix and Teprosyn Mo treatments increased soybean grain yield by $205.62 \%, 135.54 \%$ and $110.24 \%$ respectively over the control in Manga. In Nyankpala, the application of Legumefix and Teprosyn Mo+Legumefix increased soybean grain yield significantly by $22.43 \%$ and $42.10 \%$ respectively relative to the control while no significant response was observed in grain yield among treatments at Kpongu. The combined application of Teprosyn Mo+Legumefix was the most economically viable among the treatments $(\mathrm{VCR}=2.65)$.
\end{abstract}

Keywords: Economically Viable, Microbial Inoculants, Micronutrient, Nodules, Rhizobia, Soybean, Symbiosis, Yield

\section{Introduction}

In Ghana, soybean is widely cultivated in the Northern, Upper East, Upper West, Central and Volta regions where the crop is well adapted. However, production is faced with a number of constraints including low soil fertility [34], irregular rainfall patterns, drought, inadequate access to certified seed and poor agronomic practices which result in poor yields especially in the Northern savannah zones of Ghana. Although there is a growing need for chemical fertilizers to enhance crop yields [66], about $60 \%$ of African smallholder farmers are unable to afford the high prices of chemical fertilizers [68]. Moreover, the production and intensive application of chemical fertilizers in agriculture has led to a series of environmental problems [48, 69] and damage to the ecological state of agricultural systems [60]. In order to increase food production in Africa, efforts are now geared towards approaches of internal and renewable resources and the use of effective management practices [58, 62] to increase food production without compromising on sustainable agriculture. This has led to the promotion of commercial biological and chemical products intended to restore or enhance the fertility and organic matter content of soils in an eco-friendly manner [33]. [16] reported that, the presence of microorganisms in the soil is critical to the maintenance of soil function, in both natural and managed agricultural soils. The microbes are involved in key processes such as soil structure formation, decomposition of organic matter, toxin removal, and the cycling of elements - carbon, nitrogen, phosphorus, potassium, and sulfur [2]. It is also 
clear that beneficial microorganisms play key roles in suppressing soil - borne plant diseases and in promoting plant growth and changing the vegetation [21].

Biological nitrogen fixation (BNF) is seen as a cheap way to get renewable nitrogen in agriculture as it uses photosynthetically produced energy and is environmentally cleaner [3]. Many research experiments have clearly justified the positive effect of inoculation in enhancing BNF [30, 55, 62]. Although most commercial microbial and micronutrient products claim to increase BNF and consequently crop yield, their true benefits cannot be vouched for. Preliminary trials conducted in Kenya, Nigeria and Ethiopia to test some commercial microbial inoculants showed varied responses on growth and yield parameters measured. Furthermore, information regarding the use of microbial and micronutrient products in improving soybean production in Ghana is scanty.

The objective of this study was therefore to assess the effectiveness of some commercial microbial inoculant and micronutrient fertilizer in improving soybean production in the Northern savannah zones of Ghana.

\section{Materials and Methods}

\subsection{Study Sites and Soil Characteristics}

The trial was conducted at the experimental fields of the CSIR-Savannah Agricultural Research Institute at Kpongu (Latitude $09^{\circ} 59$ ' 34.0" $\mathrm{N}$ and Longitude $002^{\circ} 31^{\prime \prime} 30.3^{\prime}$ with an elevation of $315 \mathrm{~m}$ above sea level) in the Upper West region; Nyankpala (Latitudes $09^{\circ} 36^{\prime} 31.3$ ' $\mathrm{N}$ and Longitude $001^{\circ} 02$ ' 14.1 ' W with an elevation of $195 \mathrm{~m}$ above sea level) in the Northern region and Manga (Latitude $11^{\circ}-01^{\prime} \mathrm{N}$ and Longitude $00^{\circ}-16^{\circ} \mathrm{W}$ with and elevation of $249 \mathrm{~m}$ above sea level) in the Upper East region during the 2013 major cropping season. Rainfall distribution in these study sites is unimodal, with an average annual rainfall of about $1000-1200 \mathrm{~mm}$ annually [49] and mean temperatures between $26^{\circ} \mathrm{C}$ and $30^{\circ} \mathrm{C}$ with little variation throughout the year.

Initial soil sampling was done by collecting at least 8 cores from a depth of $0-15 \mathrm{~cm}$ with a soil auger following a ' $\mathrm{W}$ ' design per replicate block. Soil samples were thoroughly mixed, bulked, air-dried and composite samples taken for physico-chemical analyses and biological assays using standard protocols. Soil $\mathrm{pH}$ was determined according to the electrometric method described by [45] in a suspension 1:2.5 soil to distilled water (soil:water) ratio. The modified Walkley and Black procedure as described by [38] was used to determine organic carbon content in soil sample. The macro Kjeldahl method involving digestion and distillation as described by [54] was used in the determination of total nitrogen. The readily acid-soluble forms of phosphorus were extracted with Bray No. 1 solution $\left(\mathrm{HCl}: \mathrm{NH}_{4} \mathrm{~F}\right.$ mixture) [9, 44]. Particle size distribution was determined by the hydrometer method [18].

\subsection{Field Layout and Experimental Treatments}

All the experimental fields were weeded, ploughed and harrowed after which the layouts were done. The plot sizes measured $4.5 \times 4.5 \mathrm{~m}$ each with an alley of $1 \mathrm{~m}$ between plots. Four (4) treatments $\left(\mathrm{T}_{1}\right.$-Control, $\mathrm{T}_{2}$-Teprosyn Mo, $\mathrm{T}_{3}$ Legumefix and $\mathrm{T}_{4}$-Teprosyn Mo+Legumefix) were arranged in a Randomized Complete Block Design (RCBD) with three replications in all the experimental sites. A promiscuous medium-maturing soybean variety "Jenguma" was used as test crop. Soybean seeds were treated with Legumefix at a rate of $4.0 \mathrm{~g} \mathrm{~kg}^{-1}$ seed and $20 \mathrm{~mL}$ ( $\mathrm{kg}$ seed) $)^{-1}$ of Teprosyn Mo planted at three seeds per hole of about $5-7 \mathrm{~cm}$ deep at a spacing of $50 \mathrm{~cm} \times 5 \mathrm{~cm}$. At about $2-3$ weeks after planting (WAP), plants were thinned to two seedlings per hill.

\subsection{Estimation of Indigenous Rhizobia Population}

The most-probable-number (MPN) method [65] was used to determine the population of native rhizobia by the most probable number enumeration system (MPNES).

\subsection{Data Collection and Statistical Analysis}

At $50 \%$ podding, ten (10) soybean plants were randomly collected within the net plot of each plot. The plants were carefully uprooted by digging $15 \mathrm{~cm}$ around the plant using a spade. The plants were separated into shoots and roots. The roots were washed gently with clean water to remove all attached soil from the roots and the nodules. The nodules were counted and oven-dried at $60{ }^{\circ} \mathrm{C}$ for 48 hours to determine their dry weights. The shoots were also oven-dried at $60{ }^{\circ} \mathrm{C}$ for 72 hours and dry weights recorded for each sample. Seed yield of soybean plants were harvested at physiological maturity stage, air-dried, threshed and winnowed. The grains were oven-dried at $60{ }^{\circ} \mathrm{C}$ for 72 hours. The dry weights for each plot were then determined and used to estimate the grain yield (per hectare) [42]. One volume of milled leaves and two volumes of stems were mixed for measurement of shoot $\mathrm{N}$ and $\mathrm{P}$ content.

The collected data were subjected to Analysis of Variance (ANOVA) using the GENSTAT version 12 [24]. Means comparison of treatments showing significant effect were separated using the least significant difference (LSD) at $95 \%$ confidence level.

Partial budgeting and profitability analysis were estimated using value cost ratio as explained by [40]. The costs of Teprosyn Mo and Legumefix per hectare were USD 4.25 and USD 10.50 respectively. The farm-gate price of soybean grain was USD 40 per $100 \mathrm{~kg}$ bag in all the study locations. Prices were collected in local currencies and converted to US dollars at the prevailing exchange rates (GHф 1 to USD 2). Profitability was estimated by the value cost ratio (VCR).

\section{Results}

\subsection{Soil Characteristics and Indigenous Rhizobia Populations}

Initial physico-chemical characteristics from the study sites are presented in Table 1 . Soil $\mathrm{pH}$ values of the study sites ranged from acidic to moderately acidic (4.12 - 5.53) 
with generally low fertility status. The textural classes at the three study sites were loamy sand in Kpongu and Manga, and sandy loam in Nyankpala. The organic carbon (OC) levels at all the study sites were very low; $0.66 \%$ in Kpongu, $0.40 \%$ in Manga and $0.44 \%$ in Nyankpala. Total $\mathrm{N}$ at all the study sites were generally low ranging from $0.02-0.06 \%$. Results for available phosphorus (P) were $1.96 \mathrm{mg} \mathrm{kg}^{-1}, 1.24 \mathrm{mg} \mathrm{kg}^{-1}$ and $2.70 \mathrm{mg} \mathrm{kg}^{-1}$ for Kpongu, Manga and Nyankpala respectively which is below the critical range $\left(10.0-14.0 \mathrm{mg} \mathrm{kg}^{-1}\right)$. The populations of rhizobia in the study soils were $3.19 \times 10^{1}$, $2.79 \times 10^{1}$ and $4.36 \times 10^{1}$ cells $\mathrm{g} \mathrm{soil}^{-1}$ of soil for Kpongu, Manga and Nyankpala respectively.

Table 1. Physico-chemical and biological properties of the study sites

\begin{tabular}{|c|c|c|c|}
\hline Parameter & Kpongu & Manga & Nyankpala \\
\hline $\mathrm{pH}\left(1: 2.5 \mathrm{H}_{2} \mathrm{O}\right)$ & 5.53 & 4.12 & 5.37 \\
\hline Organic Carbon (\%) & 0.66 & 0.44 & 0.40 \\
\hline Total Nitrogen (\%) & 0.06 & 0.02 & 0.04 \\
\hline $\begin{array}{l}\text { Available Phosphorus } \\
\left(\mathrm{mg} \mathrm{kg}^{-1}\right)\end{array}$ & 1.96 & 1.24 & 2.70 \\
\hline Soil texture & Loamy sand & Loamy sand & Sandy loam \\
\hline IRP (cells $\mathrm{g}^{-1}$ of soil) & $3.19 \times 10^{1}$ & $2.79 \times 10^{1}$ & $4.36 \times 10^{1}$ \\
\hline
\end{tabular}

*IRP - Indigenous Rhizobia Population

\subsection{Shoot Biomass as Affected by the Application of Treatments}

Teprosyn Mo, Teprosyn Mo+Legumefix and Legumefix increased shoot biomass yield by $15.48 \%, 14.91 \%$ and $13.60 \%$ in Kpongu respectively over the control (Figure 1). In Manga, the highest shoot biomass was recorded in Legumefix (1338 $\left.\mathrm{kg} \mathrm{ha}^{-1}\right)$ whilst the control recorded the least $\left(790 \mathrm{~kg} \mathrm{ha}^{-1}\right.$ ) (Figure 1). In Nyankpala, percentage increases in shoot biomass over the control were $22.42 \%$, $18.17 \%$ and $6.91 \%$ for Legumefix, Teprosyn Mo+Legumefix and Teprosyn Mo respectively (Figure 1).



Figure 1. Soybean shoot biomass in the three study sites as influenced by the application of rhizobia inoculant and Teprosyn Mo.

Key: $\mathrm{T}_{1}=$ Control, $\mathrm{T}_{2}=$ Teprosyn Mo, $\mathrm{T}_{3}=$ Legumefix, $\mathrm{T}_{4}=$ Teprosyn $\mathrm{Mo}+$ Legumefix. Error bars represent the mean \pm SED.

\subsection{Nodule Dry Weight}

Rhizobia inoculation (Legumefix) increased significantly nodule dry weight in Kpongu and Manga (Figure 2). Legumefix and Legumefix+Teprosyn Mo increased nodule dry weight significantly by $130 \%$ and $83.49 \%$ respectively over the control in Kpongu. In Manga, Legumefix was significantly $(\mathrm{P}<0.05)$ effective in eliciting increased nodulation response (371 mg plt ${ }^{-1}$ ) over the control. Furthermore, nodule dry weight increased by $63.44 \%$, $43.17 \%$ and $31.28 \%$ for Legumefix, Teprosyn Mo+Legumefix and Teprosyn Mo respectively over the control. In Nyankpala, no significant $(\mathrm{P}>0.05)$ differences were observed among treatments (Figure 2).

\subsection{Grain Yield}

Figure 3 shows the effects of the treatments on grain yield in the 3 study sites. None of the treatments had significant $(\mathrm{P}>0.05)$ effect on soybean grain yield in Kpongu. However, at Manga, significant ( $\mathrm{P}$ 0.05) differences existed among the treatments with Teprosyn Mo+Legumefix producing the highest grain yield $\left(1522 \mathrm{~kg} \mathrm{ha}^{-1}\right)$ while the control recorded the lowest grain yield $\left(498 \mathrm{~kg} \mathrm{ha}^{-1}\right)$. In Nyankpala, the application of Teprosyn Mo+Legumefix increased grain yield significantly $(\mathrm{P}<0.05)$ by $42.10 \%$ while Legumefix recorded an increase of $22.43 \%$ but was not significant $(\mathrm{P}>0.05)$ relative to the control. Teprosyn Mo however, resulted in a $2.08 \%$ decline in soybean grain yield.



Figure 2. Soybean nodule dry matter in the three study sites as influenced by the application of rhizobia inoculant and Teprosyn Mo.

Key: $\mathrm{T}_{1}=$ Control, $\mathrm{T}_{2}=$ Teprosyn Mo, $\mathrm{T}_{3}=$ Legumefix, $\mathrm{T}_{4}=$ Teprosyn $\mathrm{Mo}+$ Legumefix. Error bars represent the mean \pm SED.

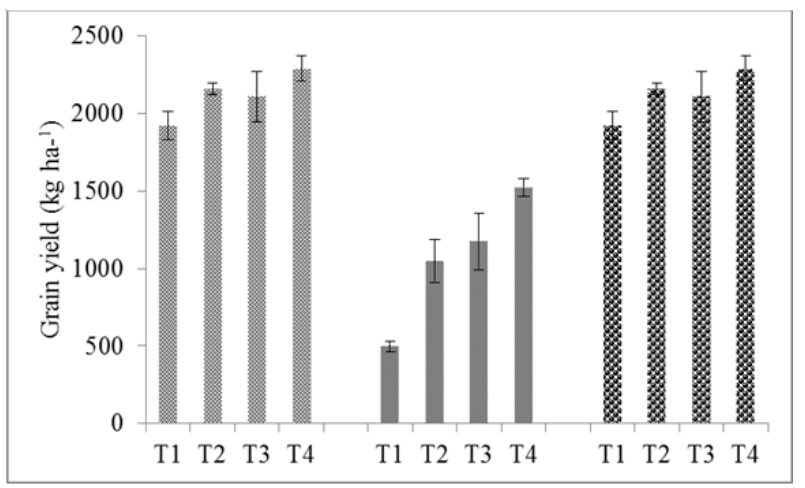

Figure 3. Soybean grain yield in the three study sites as influenced by the application of rhizobia inoculant and Teprosyn Mo.

Key: $\mathrm{T}_{1}=$ Control, $\mathrm{T}_{2}=$ Teprosyn Mo, $\mathrm{T}_{3}=$ Legumefix, $\mathrm{T}_{4}=$ Teprosyn Mo + Legumefix. Error bars represent the mean \pm SED. 


\subsection{Economic Assessment of Products Tested}

The economic analysis showed that additional benefits were achieved when Teprosyn Mo, Legumefix and Teprosyn Mo + Legumefix were applied except for Teprosyn Mo in Nyankpala. The value cost ratio analysis also showed that all the treatments had a VCR below 2 except the combined application of Teprosyn Mo + Legumefix in Manga $(\mathrm{VCR}=$ 2.65).

All the treatments had a VCR below 2 except Teprosyn Mo+Legumefix in Manga $(\mathrm{VCR}=2.65)$.

\section{Discussion}

The soil fertility status at Kpongu, Manga and Nyankpala was generally low (Table 1). This is in line with [11], who reported that soil nutrient levels in the Savannah zones of Ghana are particularly low with high $\mathrm{pH}$ values, low organic matter, nitrogen and available P levels. Soils of Nyankpala had relatively higher indigenous rhizobia population than Kpongu and Manga (Table 1). Nonetheless, the soils of the study sites had a low number of rhizobia population $(<50$ cells $\mathrm{g}^{-1}$ soil) according to [53].

No significant differences in shoot biomass dry weight were observed among treatments tested in all the study sites (Figure 1). This is in agreement with [42, 43] who reported that inoculation of soybean variety (TGx1448-2E) did not significantly increase shoot yield. A temporary drought, low and poorly distributed rainfall during crop growth in all study sites could be contributory factors. Plants whose roots have been subjected to stress deficient in soil water cause at least in part a change in the amount and kind of growth regulators supplied from the roots which result in reduced shoot growth [17].

Legumefix increased nodule dry weight significantly over the control and Teprosyn Mo in Kpongu (Figure 2). This is in agreement with [31], who observed that rhizobia inoculation significantly increased nodule dry weight of soybean over control. The results also indicated that Teprosyn Mo treated plots produced the lowest nodule dry weight. This observation was however, in contrast with those of [32] and [39] who indicated that nodule number and dry weight of cowpea were increased by Mo application. This observation can also be attributed to the acidic nature of the soil ( $\mathrm{pH} 5.53$ ) in the study area. In the soil solution, Mo exists as an anion at soil $\mathrm{pH}$ above 4 [36] but becomes deficient under $\mathrm{pH}$ levels below 6.0 [47]. In Manga, Legumefix recorded the highest nodule dry weight (Figure 2). Soils in Manga recorded the lowest indigenous rhizobia population $\left(2.79 \times 10^{1}\right)$ and as such responded significantly to rhizobia inoculation. According to [53], where there are low ( $<50$ rhizobium bacteria $\mathrm{g} \mathrm{m}^{-1}$ soil) naturalised populations of rhizobia specific to a target legume, the introduction of new strains by seed inoculation is normally successful. Therefore the introduced strain provided enough viable and effective rhizobia to participate in the infection process [13] for higher nodulation. Nodule dry weight in the sole Teprosyn Mo and combined Teprosyn Mo+Legumefix treatments did not differ significantly from the control in Manga (Figure 2). This could be explained by the high acidic level of the soil as stated by [47] that, in acidic soils $(\mathrm{pH}<5.5)$, Mo availability decreases as anion adsorption to soil oxides increase. Due to the saline or acidic sources of micronutrients, seed treatment with Mo can damage rhizobia, drastically affecting the survival of inoculated bacteria on the seeds, thus resulting in reduced nodulation and $\mathrm{N}_{2}$ fixation $[4,22]$.

No significant differences in nodule dry weight were observed among the treatments in Nyankpala (Figure 2). This agrees with the findings of [42] and [14] who reported no significant increase in nodulation following rhizobia inoculation. Soils in this study site recorded the highest indigenous rhizobia population of $4.36 \times 10^{1}$. High population density of indigenous and naturalized rhizobia population of $1 \times 10^{2}$ rhizobia cell $\mathrm{g}^{-1}$ soil has been reported to prevent nodulation and displace applied inoculums [10,27, 52]. This suggests that failure of this soil to respond to rhizobia inoculation was primarily due to the presence of sufficient number of indigenous rhizobia population to adequately compete with the introduced strain for nodule occupancy [5]. Since the indigenous rhizobia are present through the soil while the introduced rhizobia are only present on the seed coat, there is the competitive advantage of the native rhizobia over the introduced strain (Denton et al., 2002). Several reports have also indicated no improvement or toxicity from Mo seed-coating through suppressive effects of salts used as Mo sources on Bradyrhizobium affecting bacterial survivability and nodulation $[4,12]$.

Treatment effects on grain yield in Kpongu were not significantly different from the control (Figure 3). A study by [25] also confirms that soybean yield did not differ between inoculant products and the controls. The lack of significant grain yield response in the study sites could be attributed to the temporary drought experienced during plant growth and mineral nutrient deficiencies $(\mathrm{N}, \mathrm{P})$ which are the major constraints limiting legume $\mathrm{N}_{2}$ fixation and yield [41]. [50] suggested a potential negative yield response from inoculation under extreme drought conditions occurring during pod fill due to an increased vegetative sink.

In Manga, significant differences in grain yield were observed among treatments with Teprosyn Mo+Legumefix recording the highest (1522 $\mathrm{kg} \mathrm{ha}^{-1}$ ) (Figure 3). This is in confirmation with a multi-locational trial conducted by [29] at farmers' fields in Bangladesh, which showed that, the efficiency of seed treatment with Mo may be further enhanced by adding rhizobium as yield increases were $37 \%$ $90 \%$ over the untreated control. According to [12], Mo in legumes serves as an additional function to help root nodule bacteria to fix atmospheric $\mathrm{N}$ resulting in increased yield which account for over $200 \%$ increase in grain yield. Legumefix, a rhizobia inoculant helps to boosts the natural population of beneficial nitrogen-fixing bacteria to form effective nodules that are responsible for effective BNF [15] and explains the over $100 \%$ increase in grain yield compared 
to the control. Furthermore, a series of field experiments in DR-Congo and Nigeria resulted in significant yield increases of $80-300 \%$ with inoculation $[6,46]$.

Significant differences were observed among treatments in grain yield at Nyankpala (Figure 3). Teprosyn $\mathrm{Mo}+$ Legumefix and Legumefix increased grain yield by $42 \%$ and $22 \%$ respectively over the control while Teprosyn Mo recorded the lowest grain yield. This is in line with a study by [8] who observed that addition of molybdenum alone gave a lower yield in soybean than its addition with rhizobium inoculant.

\section{Conclusion}

The application of Legumefix resulted in over $50 \%$ increase in soybean yield relative to the control in all the study sites and was further enhanced when combined with Teprosyn Mo with a relative increase of $205.62 \%$ in Manga. The co-application of Teprosyn Mo+Legumefix was the most profitable treatment $(\mathrm{VCR}=2.65)$ in Manga. Farmers in Manga can therefore obtain greater economic benefit from the combined application of Teprosyn Mo and Legumefix for soybean production.

\section{Acknowledgment}

The Bill and Melinda Gate Foundation and Compro II project are acknowledged for the sponsorship and financial support of this research project.

\section{References}

[1] A.O. Adesemoye and J.W. Kloepper, "Plant-microbes interactions in enhanced fertilizer use efficiency". Appl Microbiol Biotechnol 85, 2009, pp.1-12.

[2] A.O. Adesemoye and D. Egamberdieva, "Bacteria in Agrobiology". Crop Productivity, 2013, Chapter 2 Beneficial Effects of Plant Growth-Promoting Rhizobacteria on Improved Crop Production: Prospects for Developing Economies.

[3] M. Albareda and D.N. Rodrigues, F. J. Temprano, "Soybean inoculation: Dose, $\mathrm{N}$ fertilizer supplementation and rhizobia persistence in soil". Field Crop Research 113, 2009, pp. $352-$ 356.

[4] U. B. Albino and R. J. Campo, "Effect of sources and molybdenum doses survives in NCIA of Bradyrhizobium and biological nitrogen fixation in soybeans". Pesq. Agro. Bras. 36, 2001, pp. 527-534.

[5] A.M.K. Al-Falih, "Factors affecting the efficiency of symbiotic nitrogen fixation by Rhizobium". Pakistan Journal of Biological Sciences 5(11), 2002, pp. 1277-1293.

[6] A. Bala, "Recent advances in soybean inoculum research and applications: Towards enhancing productivity in smallholder agriculture", Paper presented at an International Workshop on Rhizobium Inoculation, held at Impala Hotel, Arusha Tanzania, 2008, pp. 17-21.
[7] G.A. Barros de Carvalho, J.S. Silva, F.C.M. Guimarães, L. Costa and M. Hungría. BMC Genomics. 14, 2003, pp. 1.

[8] K.A.J. Bassam and M.S. Halimi, "Effects of Molybdenum on Biological Nitrogen Fixation by Combination of Rhizobium and Azospirillum in Soybean under Drip Irrigation System". International Journal of Life Sciences Biotechnology and Pharma Research Vol. 1, No. 2, 2012, pp. 63-77.

[9] R. N. Bray and L.T. Kurtz, "Determination of total organic and available farms of phosphorus in soils". Soil Science 59, 1945, pp. 39-45.

[10] J. Brockwell, P.J Bottomley and J.E Thies, "Manipulation of rhizobia microflora for improving legume productivity and soil fertility: a critical assessment”. Plant and Soil, 174, 1995, pp. 143-80.

[11] M.M. Buri, R.N. Iassaka, H. Fujii and T. Wakatsuki, "Comparison of Soil Nutrient status of some Rice growing Environments in the major Agro-ecological zones of Ghana. International Journal of Food, Agriculture \& Environment Vol. 8 (1), 2009, pp. 384-388.

[12] R.J. Campo, U.B. Albino and M. Hungria, "Importance of molybdenum and cobalt to the biological nitrogen fixation". In: F.O. Pedrosa, M. Hungria, G. Yates, W.E. Newton (eds.). Nitrogen Fixation: From Molecules to Crop Productivity, 2000, pp. 597-598, Springer, Netherlands.

[13] G. Catroux, A. Hartmann and C. Revellin, "Trends in rhizobial inoculant production and use". Plant and soil 230, 2001, pp. 21-30.

[14] G.N. Chemining'wa, J.W. Muthomi, S.W.M. Theuri, "Effect of rhizobia inoculation and starter-N on nodulation, shoot biomas and yield of grain legumes". Asian Journal of Plant Sciences 6, 2007, pp. 1113-1118.

[15] J. Chen, "The combined use of chemical and organic fertilizers and/or biofertilisers for crop growth and soil fertility". Paper presented at the International Workshop on Sustained Management of the Soil-Rhizosphere System for Efficient Crop Production and Fertilizer Use 16-20 October 2006. Land Development Department, Bangkok 10900 Thailand, 2008.

[16] M.S. Dardanelli, S.M. Carletti, N.S. Paulucci, D.B. Medeot, E.A. Rodriguez Caceres, F.A.Vita, M. Bueno, M. V. Fumero and M.B. Garcia, "Benefits of plant growth-promoting rhizobacteria and rhizobia in agriculture". In: Maheshwari DK (ed) Plant growth and health promoting bacteria, vol 18, 2010, Microbiology monographs. Springer, Berlin, pp 1-20

[17] W.J. Davies and J. Zhang, "Root signals and the regulations of growth and development of plants in drying soil". Annu. Rev. Plant Physiol. Mol. Biol. 42, 1991, pp. 55-76.

[18] P.R. Day, "Experimental confirmation of hydrometer theory" Soil Sci. 75, 1953, pp. 181-186.

[19] R. Deaker, E. Hartley and G. Gemell, "Conditions Affecting Shelf-Life of Inoculated Legume Seed". Agriculture 2, 2012, pp. 38-51.

[20] M.D. Denton, R. Coventry, P.J. Murphy, J.G. Howieson and W.D. Bellotti, "Competition between inoculant and naturalised Rhizobium leguminosarum bv. trifolii for nodulation of annual clovers in alkaline soils". Aust J 2002, Agric Res. doi: 10.1071/AR01138. 
[21] J.W. Doran, M. Sarrantonio and M.A. Liebig, "Soil health and sustainability". Adv Agron 56, 1996, pp. 2-54

[22] EMBRAPA, Empresa Brasileira de Pesquisa Agropecu' aria: Brazilian Research Company Agropecu' aria: Brazilian System of classification the soil los. 2nd Edn., Rio de Janeiro, Embrapa Solos, pp., 306. Portugese.

[23] Food and Agriculture Organization, "Plant nutrition for food security, a guide for integrated nutrient management". FAO Fertiliser and Plant Nutrition Bulletin. No.16, 2006, pp.121. Rome, Italy.

[24] Food and Agriculture Organization, "Fertilizer use by crops in Ghana. Land and Plant Nutrition Management Service. Land and Water Development Division”, 2005.

[25] B.J. Furseth, C.R. Shawn and A. Jean Michel, "Soybean Response to Soil Rhizobia and Seed-applied Rhizobia in Wisconsin”. Research. Crop Sci. 52, 2012, pp. 339-344.

[26] GenStat, Release 11.1,2010, VSN International Ltd. Oxford, UK.

[27] P.H. Graham, "Some problems of nodulation and symbiotic N2 fixation in Phaseolus vulgaris L. Field Crops Res; 4, 1981, pp. 93-112.

[28] K.L. Hale, S.P. McGrath, E. Lombi, M.S. Stack, N. Terry, I.J. Pickering, N.G. Graham and E.A.H. Pilon-Smith, "Molybdenum Sequestration in Brassica Species. A Role for Anthocyanins" Plant Physiol. 126, 2001, pp. 1391-1402.

[29] C. Johansen, A.M. Musa, J.V.D.K. Kumar Rao, D. Harris, M.Y. Ali, A.K.M Shahidullah and J.G. Lauren, "Correcting molybdenum deficiency of chickpea in the high barind tract of Bangladesh”. J. Plant Nutr. Soil Sci. 170,2006b, pp. 752-761.

[30] B.D. Kadiata, S. Schubert and F. Yan, "Assessment of different inoculants of Bradyrhizobium japonicum on nodulation, potential $\mathrm{N}_{2}$ fixation and yield performance of soybean (Glycine max L.). J Anim Plant Sci 13, 2012, pp. 1704-1713.

[31] P. Katulanda, "Symbiotic nitrogen fixation and seed development of genetically modified soybean in relation to bradyrhizobium inoculation and nitrogen use under acidic and saline dykeland soil conditions. MSc. Thesis, 2011.

[32] M. Krishnappa, C.N. Srinivasan, P.W. Basarkar and J.A. Sastry, "Effects of iron, zinc and molybdenum on protein content of groundnut varieties". Journal of Maharashtra Agricultural Universities, 17(2)1992, pp. 232-235.

[33] M.A. Laditi, O.C. Nwoke, M. Jemo, R.C. Abaidoo and A.A. Ogunjobi, "Evaluation of microbial inoculants as biofertilizers for the improvement of growth and yield of soybean and maize crops in savanna soils. African Journal of Agricultural Research, 7(3), 2012, pp. 405-413.

[34] I.Y.D. Lawson, E.A. Mensah and E.N. Yeboah, "Improving the establishment and yield of soybean through planting depth and land preparation methods in northern Ghana". West African Journal of Applied Ecology 14, 2008, pp. 1-8

[35] R. Lemus, Forage News., 5(9), 3.2001, 17, 635, 2012.

[36] W.L. Lindsay, "Inorganic equilibria affecting micronutrients in soils". In J.J. Mortvedt, F.R. Cox, L.M. Shuman and R.M. Welch (eds.), Micronutrients in Agriculture. $2^{\text {nd }}$ ed. SSSA Book Series No. 4. Soil Science Society of America, Madison, Wisconsin, 1991, pp. 89-112.
[37] J. Maingi, C.A. Shisanya, N.M. Gitonga and B. Hornetz, "Biological nitrogen fixation in selected legumes of the semiarid Makueni District of Southeast Kenya; Der Tropenlandwirt". Journal of Agriculture in the Tropics and Subtropics; 100(2), 1999, pp. 205-213.

[38] D.W. Nelson and L.W. Sommers, "Total carbon, organic carbon and organic matter". In: A.L. Page, R.H. Miller and D.R. Keeney. (eds.). Methods of soil analysis. Part 2. Second edition. Chemical and microbiological properties. American Society of Agronomy and Soil Science Society of America. Madison, Wisconsin USA.1982, pp. 301-312.

[39] S. Noor, M.A. Hannan and M.S. Islam, "Effect of molybdenum and boron on the growth and yield of groundnut". Indian Journal of Agricultural Research, 31(1), 1997, pp. 51-58.

[40] G. Nziguheba, C.A. Palm, T. Berhe, G. Denning, A. Dicko, O. Diouf, W. Diru, R. Flor, F. Frimpong, R. Harawa, B. Kaya, E. Manumbu, J. McArthur, P. Mutuo, M. Ndiaye, A. Niang, P. Nkhoma, G. Nyadzi, J. Sachs, C. Sullivan, G. Teklu, L. Tobe and P.A. Sanchez, "The African Green Revolution: Results from the Millennium Villages Project", 2010.

[41] G.W. O'Hara, N. Boonkerd and M.J. Dilworth, "Mineral constraints to nitrogen fixation". Plant Soil 108, 1988, pp. 93 110 .

[42] J.A. Okogun, N. Sanginga, R. Abaidoo, K.E. Dashiell and J. Diels, "On-farm evaluation of biological nitrogen fixation potential and grain yield of Lablab and two soybean varieties in the northern Guinea savanna of Nigeria". Nutr. Cycl. Agroecosyst. 73, 2005, pp. 267-275.

[43] J.A. Okogun, B.T. Otuyemi and N. Sanginga, "Soybean yield determinant and response to rhizobial inoculation in an onfarm trial in northern guinea savanna of Nigeria". W Afri. J. Appl Ecol. 6, 2004, pp. 30-39.

[44] S.R. Olsen and L.E. Sommers, "Phosphorus. In: Page, A.L., Miller, R.H. and Keeney, D. R. (eds.). Methods of soil analysis". Part 2. Chemical and microbiological properties. Second edition. American Society of Agronomy and Soil Science Society of America, Madison, Wisconsin USA.1982, pp. $403-430$.

[45] A.L. Page, R.H. Miller and D.R. Keeney, "Methods of soil analysis. Part 2. Chemical and microbiological properties". 2nd Edition. Agronomy series 9, ASA, SSSA, Madison, Wis. USA, 1982.

[46] V. Ranga-Rao, G. Thottapilly and A. Ayanaba, "Studies on the persistence of introduced strains of Rhizobium japonicum in soil during fallow and effects on soybean growth and yield", in: BNF Technology for Tropical Agriculture, 1981, pp. 309315 .

[47] K.J. Reddy, L.C. Munn and L. Wang, "Chemistry and mineralogy of molybdenum in the terrestrial environment". In U.C. Gupta (ed.), Molybdenum in Agriculture. 1997, pp. 4-22. Cambridge University Press, Cambridge.

[48] J. Richter and M. Roelcke, "The N-cycle as determined by intensive agriculture examples from central Europe and China. Nutr. Cycl. Agroecosyst. 57, 2000, pp. 33-46.

[49] SARI. Savanna Agricultural Research Institute. Annual Report, 1996. 
[50] T.J. Schultz and K.D. Thelen, "Soybean seed inoculant and fungicidal seed treatment effects on soybean. Crop science, 48(5), 2008, pp. 1975-1983.

[51] N.S.W. Simiyu, D. Tarus, J. Watiti and F. Nang'ayo, "Effective Regulation of bio-fertilizers and bio-pesticides: A potential avenue to increase agricultural productivity. COMPRO II, Policy Series, 2003, No, 1.

[52] P.W. Singleton and J.W. Tavares, "Inoculation response of legumes in relation to the number and effectiveness of indigenous rhizobium population". Applied and Environmental Microbiology, 51:1986, pp. 1013 - 1018.

[53] J. Slattery and D. Pearce, "The impact of background rhizobial population on inoculation response". In. Herridge, D (Eds). Inoculants and Nitrogen fixation in Vietnam. ACIAR proceedings, 2002.

[54] Soils Laboratory Staff, "Royal Tropical Institute. Analytical methods of the service laboratory for soil, plant and water analysis". Part 1: Methods of soil analysis. Royal Tropical Institute. Amsterdam, 1984.

[55] T. Solomon, L.M. Pant and T. Angaw T, ISRN Agronomy, 1, 2012.

[56] P. Somasegaran and H.J. Hoben, "Handbook for Rhizobia: Methods in Legume - Rhizobium technology". Springer Verkag, New York, USA, 1994, pp 366. 69.

[57] R.G.D. Steel and J.H. Torrie, "Principles and Procedures of Statistics". McGraw-Hill Book Co. Int. New York, 1987, pp. 276.

[58] A.V. Sturz, B.R. Christie and S. Nowak S, "Bacterial endophytes: potential role in developing sustainable systems of crop production". Critical Reviews in Plant Sciences 19, 2000, pp.1-30.

[59] M.M. Tahir, M.K. Abbasi, N. Rahim, A. Khaliq and M.H. Kazmi, "Effect of Rhizobium inoculation and N P fertilization on growth, yield and nodulation of 149 soybeans (Glycine $\max$ L.) in the sub-humid hilly region of Rawalakot Azad Jammu and Kashmir, Pakistan". African Journal of Biotechnology. 8: 2009, 6191- 6200.
[60] S.J.A. Villarreal, A. Ilyina, L.P. Mendez, V.R. Torres, R. Rodriguez, B.C. Lopez and J.R. Martinez, "Isolation of microbial groups from a seaweed extract and comparison of their effects on a growth of pepper culture (Capsicum annuum L.)". Âecth. Mock, 44, 2003, pp. 1.

[61] J.M. Vincent, "A Manual for Practical Study of the Root Nodule Bacteria". Blackwell Scientific Publications, Oxford, 1970, pp. 164.

[62] S.P. Wani and K.K. Lee, "Role of microorganisms in sustainable agriculture. In: (Behl, R.K., Khurana, A.L., and Dogra, RC. (eds.)). Plant microbe interaction in sustainable agriculture. CCS HAU, Hisar and MMB, New Delhi. 1996, pp. 62-88.

[63] R.W. Weaver and L.R. Frederick, "A new technique for most probable number counts of rhizobia". Plant Soil. 36, 1972, pp. 219-222.

[64] D.T. Westermann, "Nutritional requirements of potatoes". Am. J. Potato Res. 82, 2005, pp. 301-307.

[65] P. Woomer, P.W. Singleton and BB. Bohlool, "Reliability of the most-probable number technique for enumerating rhizobia in tropical soils". Appl. Environ. Microbiol. 54, 1990, pp. 1494-1497.

[66] World Bank, Sustainable land management source book. Washington DC: World Bank, 2008.

[67] T. Yamakawa and Y. Saeki Y A Comprehensive Survey of International Soybean Research - Genetics, Physiology, Agronomy and Nitrogen Relationships", In: J. E. Board (Ed.), (In Tech, New York, USA), 2013, pp. 83.

[68] D. Yanggen, V. Kelly, T. Reardon and A. Naseem, “ Incentives for fertilizer use in sub-Saharan Africa: A review of empirical evidence on fertilizer response and profitability", MSU International Development Working Paper No. 70, Department of Agricultural Economics, Michigan State University, East Lansing, USA, 1998.

[69] J.G. Zhu, Y. Han, G. Liu, Y.L. Zhang and X.H. Shao, "Nitrogen in percolation water in paddy fields with a rice/wheat rotation". Nutr. Cycl. Agroecosyst. 57, 2000, pp. 75-82. 